\title{
Gold supported on surface acidity modified Y-type and iron/Y-type zeolite for CO oxidation
}

\author{
Jiunn-Nan Lin, Jen-Ho Chen, Chih-Yang Hsiao, Yih-Ming Kang, Ben-Zu Wan* \\ Department of Chemical Engineering, National Taiwan University, Taipei 106, Taiwan, ROC
}

Received 22 June 2001; received in revised form 20 September 2001; accepted 20 September 2001

\begin{abstract}
A modified method for the preparation of gold in Y-type zeolite was developed in this research. Prior to the preparation of gold catalysts, the surface property of the zeolite (with or without iron) was adjusted in a $1 \mathrm{~N}$ sodium nitrate solution at $\mathrm{pH}$ 6. After drying, the zeolite was added into a chloroauric acid solution at $\mathrm{pH} 6$ for gold loading. The resulted catalysts (i.e. $\mathrm{Au} / \mathrm{Y}$ or $\mathrm{Au} / \mathrm{Fe} / \mathrm{Y}$ ) possessed much better activity and stability for $\mathrm{CO}$ oxidation than those (i.e. $\mathrm{Au} / \mathrm{Y}(\mathrm{NP})$ or $\mathrm{Au} / \mathrm{Fe} / \mathrm{Y}(\mathrm{NP})$ ) without any surface pretreatment. Transmission electron microscopy (TEM) and X-ray photoelectron spectroscopy (XPS) studies indicate that the gold particles in $\mathrm{Au} / \mathrm{Y}$ are smaller and more uniformly distributed than those in Au/Y(NP). XPS and temperature-programmed reduction (TPR) results suggest the strong interaction between gold and iron in Y-type zeolite. Furthermore, it was found from this research that $\mathrm{Au} / \mathrm{Fe} / \mathrm{Y}$ had full initial activity for $\mathrm{CO}$ oxidation at $0^{\circ} \mathrm{C}$ and $\mathrm{Au} / \mathrm{Y}$ required an induction period to reach a comparable activity to $\mathrm{Au} / \mathrm{Fe} / \mathrm{Y}$. However, the stability of the activated $\mathrm{Au} / \mathrm{Y}$ was much better than that of $\mathrm{Au} / \mathrm{Fe} / \mathrm{Y}$. It can be concluded from XPS results that the formation of carbonate-like species, which covered the active sites for $\mathrm{CO}$ oxidation, was the main cause for the deactivation of $\mathrm{Au} / \mathrm{Fe} / \mathrm{Y}$. On the other hand, TEM study suggests that the sintering of nano-gold particles was the main reason for the slight deactivation of Au/Y. @ 2002 Elsevier Science B.V. All rights reserved.
\end{abstract}

Keywords: Gold; Y-type zeolite; Iron; Iron oxide; CO oxidation; Surface acidity

\section{Introduction}

Gold did not attract much attention in heterogeneous catalysis because of its chemical inertness and the difficulty for obtaining highly dispersed samples. However, several years ago Haruta et al. [1-3] found when co-precipitation of gold with various metal oxides, the gold catalysts possessed a dramatic activity for low-temperature $\mathrm{CO}$ oxidation. They discovered that gold nanoparticles supported on $\mathrm{Co}_{3} \mathrm{O}_{4}, \mathrm{Fe}_{2} \mathrm{O}_{3}$, and $\mathrm{TiO}_{2}$ oxides have exceptionally high activity for many reactions. It is believed that these are correlated

\footnotetext{
* Corresponding author. Fax: +886-2-23623040.

E-mail address: benzuwan@ccms.ntu.edu.tw (B.-Z. Wan).
}

with the support property, the preparation method, and particularly the size of the Au clusters [4]. Since then many studies have been devoted to prepare ultrafine gold particles on the surface of metal oxides [5-7] and zeolites [8-15] for various reactions over the last few years.

It has been studied that small gold particles can be stabilized via inserting gold into the cages of zeolites [8-15]. Different kinds of Au/Zeolites have been prepared for NO reduction and CO oxidation [8-13]. Ichikawa and coworkers [8-10] used $\mathrm{Au}_{2} \mathrm{Cl}_{6}$ as a precursor to prepared $\mathrm{Au}(\mathrm{I}) / \mathrm{NaY}$ via a solid-vapor reaction. Fraissard and coworkers [14-15] used $\left[\mathrm{Au}(\mathrm{en})_{2}\right] \mathrm{Cl}_{3}$ to prepare $\mathrm{Au} / \mathrm{NaHY}$ via a cation exchange method. Nevertheless, these gold catalysts 
were contaminated by chloride residuals. An additional high temperature pretreatment was required to activate the catalyst, which resulted in sintering of gold particles. Kang and Wan [11-13] in our previous research, developed a more convenient method to prepare $\mathrm{Au} / \mathrm{Y}$ and $\mathrm{Au} / \mathrm{Fe} / \mathrm{Y}$ ( $\mathrm{Y}$ is the $\mathrm{Y}$-type zeolite) in the chloroauric acid solution $\left(\mathrm{HAuCl}_{4} \cdot 3 \mathrm{H}_{2} \mathrm{O}\right)$. It was found that the as-prepared $\mathrm{Au} / \mathrm{Y}$ showed high initial activity for low temperature $\mathrm{CO}$ oxidation but poor stability. However, the as-prepared $\mathrm{Au} / \mathrm{Fe} / \mathrm{Y}$ showed almost no activity and it can possess catalytic activity only after high temperature reduction. The low activity of as-prepared $\mathrm{Au} / \mathrm{Fe} / \mathrm{Y}$ was also caused by the residual $\mathrm{Cl}^{-}$species.

From the later study in our laboratory [16,17], it was concluded that gold loading and $\mathrm{CO}$ oxidation activity over $\mathrm{Au} / \mathrm{Y}$ and $\mathrm{Au} / \mathrm{Fe} / \mathrm{Y}$ were affected by the $\mathrm{pH}$ of chloroauric acid solution. It is preferred to prepare gold in Y-type zeolite in the solution with $\mathrm{pH}$ between 6 and 7. However, it was noticed that there is surface acidity on zeolite $\mathrm{Y}$, which may not fit for loading the gold species. Therefore, before loading gold, an attempt was made in our laboratory to modify the surface acidity of the Y-type zeolite in a sodium nitrate solution at $\mathrm{pH}$ 6. Surprisingly, it was found that gold species prepared on these surface modified zeolites showed much higher activities and maintained better stability during $\mathrm{CO}$ oxidation. Therefore, in this paper the detailed procedures for the preparation of $\mathrm{Au} / \mathrm{Y}$ and $\mathrm{Au} / \mathrm{Fe} / \mathrm{Y}$ by the modified method are reported. The catalysts are compared with those without surface modification. The results of the characterization by X-ray diffraction (XRD), X-ray photoelectron spectroscopy (XPS), transmission electron microscopy (TEM) and temperature-programmed reduction (TPR) are presented. It is believed that the effects of surface modification on Y-type zeolite for loading gold species and for $\mathrm{CO}$ oxidation can be better understood from this research.

\section{Experimental}

\subsection{Catalysts}

Y-type zeolite with $\mathrm{Si}: \mathrm{Al}=2.3$, sodium loading $=$ 3.4 wt. $\%$ from Conteka was calcined at $550{ }^{\circ} \mathrm{C}$ in air for $4 \mathrm{~h}$ (designated $\mathrm{Y}(\mathrm{NP})$ ) before it was used in this research. Two kinds of $\mathrm{Fe} / \mathrm{Y}$ were prepared in this study. Fe-imp/Y(NP) was prepared by the incipient-wetness impregnation of aqueous solution of $\mathrm{Fe}\left(\mathrm{NO}_{3}\right)_{3} \cdot 9 \mathrm{H}_{2} \mathrm{O}$ (Riedel-deHaen) into $\mathrm{Y}(\mathrm{NP})$. The impregnated sample was dried at $60^{\circ} \mathrm{C}$ for $4 \mathrm{~h}$, then calcined at $550{ }^{\circ} \mathrm{C}$ for $4 \mathrm{~h}$ in air. Fe-ion/Y(NP) was prepared by ion exchanging of $\mathrm{Fe}\left(\mathrm{NO}_{3}\right)_{3} \cdot \mathrm{P} \mathrm{H}_{2} \mathrm{O}$ with $\mathrm{Y}(\mathrm{NP})$ in the aqueous solution at ambient temperature for $6 \mathrm{~h}$. After filtration and washing by deionized water, the sample was dried at $60^{\circ} \mathrm{C}$ and calcined at $550^{\circ} \mathrm{C}$ for $4 \mathrm{~h}$ in air. For the gold loading process, $\mathrm{Y}(\mathrm{NP}), \mathrm{Fe}-\mathrm{imp} / \mathrm{Y}(\mathrm{NP})$ or Fe-ion/Y(NP) was directly charged into the chloroauric acid solution (Merck), which was pre-adjusted to $\mathrm{pH} 6$ by a $\mathrm{NaOH}$ solution for 2 days. After filtration, washing and drying, the resulted samples were designated as $\mathrm{Au} / \mathrm{Y}(\mathrm{NP})$, $\mathrm{Au} / \mathrm{Fe}-\mathrm{imp} / \mathrm{Y}(\mathrm{NP})$ or $\mathrm{Au} / \mathrm{Fe}-\mathrm{ion} / \mathrm{Y}(\mathrm{NP})$. However, for the new process developed in this research, prior to the gold loading process, the supports (i.e. Y(NP), $\mathrm{Fe}-\mathrm{imp} / \mathrm{Y}(\mathrm{NP})$, and $\mathrm{Fe}-\mathrm{ion} / \mathrm{Y}(\mathrm{NP})$ ) were put into a $1 \mathrm{~N} \mathrm{NaNO}_{3}$ solution and the solution $\mathrm{pH}$ was adjusted to 6 by a $1 \mathrm{~N}$ sodium hydroxide solution. After the equilibrium was reached (generally, it takes 2 days), the samples was filtered and dried at $60^{\circ} \mathrm{C}$. These samples were designated as $\mathrm{Y}, \mathrm{Fe}-\mathrm{imp} / \mathrm{Y}$ and $\mathrm{Fe}$-ion/Y. Then the samples were for the following example process for loading gold: $4 \mathrm{~g}$ of $\mathrm{Y}, \mathrm{Fe}-\mathrm{imp} / \mathrm{Y}$ or $\mathrm{Fe}-$ ion/ $\mathrm{Y}$ was added into a $500 \mathrm{ml}$ chloroauric acid solution $(0.032 \mathrm{wt} . \%$ of $\mathrm{Au}, \mathrm{pH}=6)$. Under stirring, the solution was heated to $80^{\circ} \mathrm{C}$ and maintained at this temperature for $16 \mathrm{~h}$. After filtration, washing and drying, the as-prepared gold catalysts were designated as $\mathrm{Au} / \mathrm{Y}, \mathrm{Au} / \mathrm{Fe}$-imp/Y and $\mathrm{Au} / \mathrm{Fe}$-ion/Y. Because a question about why not adjusting the surface acidity of Y-type zeolite during the gold loading process was raised, the following procedures were used for preparing a reference sample: $4 \mathrm{~g}$ of $\mathrm{Y}(\mathrm{NP})$ was added into $500 \mathrm{ml}$ of $0.032 \mathrm{wt} . \%$ of chloroauric acid solution $(\mathrm{pH}=6)$. Under stirring, the $\mathrm{pH}$ of the solution was monitored and adjusted to $\mathrm{pH} 6.8$ (which was the filtrate $\mathrm{pH}$ of $\mathrm{Au} / \mathrm{Y}$ solution at the end of preparation) for the first half an hour at room temperature. Then the solution under the condition without adjusting $\mathrm{pH}$ was heated to $80^{\circ} \mathrm{C}$ and maintained at this temperature for $16 \mathrm{~h}$. After filtration, washing and drying, the as-prepared sample was designated as $[\mathrm{Au} / \mathrm{Y}(\mathrm{NP})]_{\mathrm{pH}}$. 


\subsection{Characterization}

The elemental content in each sample was determined by an AA unit (GBC 906) and by an ICP-AES unit (Kontro Plasmakon Model S-35). The zeta potential of the supports were measured by a Zetasizer 2000 (Malvern). The TEM pictures were taken using a Hitachi H7100 electron microscope operated at $75 \mathrm{kV}$. For the measurement of TPR, the experimental procedures and the apparatus were described in detail in [18]. The samples were purged in a carrier gas (mole ratio of $\mathrm{H}_{2}: \mathrm{N}_{2}=1: 9$ ) of $30 \mathrm{ml} / \mathrm{min}$ flow rate at room temperature for $20 \mathrm{~min}$ before the measurement. For the measurement of binding energy, a PHI 1600 ESCA spectrometer, using $\mathrm{Mg} \mathrm{K} \alpha$ monochromatic $\mathrm{X}$-rays, was applied. All the measured binding energies (BE) were referred to the $\mathrm{C} 1 \mathrm{~s}$ line at $284.6 \mathrm{eV}$. The XRD measurements were carried out by a MAC Science Diffractometer (Model MXP-3) with $\mathrm{Cu} \mathrm{K} \alpha$ radiation at $40 \mathrm{kV}$ and $30 \mathrm{~mA}$.

\subsection{Catalytic activity}

Carbon monoxide oxidation was carried out in a quartz-tubular reactor $(7 \mathrm{~mm}$ i.d.) under atmospheric pressure. The catalysts, which contained a fixed amount of gold, were used for the reaction. $32.7 \mathrm{ml} / \mathrm{min}$ of air and $0.33 \mathrm{ml} / \mathrm{min}$ of carbon monoxide (99.3\%, CP grade, Linde Division, Union Carbide) were purified by $4 \AA$ molecular sieves, then mixed and flowed into the reactor for the reaction. Shimadzu GC-8A gas chromatograph was used for the analysis of the composition in the reactor outstream. A Carboxy-2000 column was applied for the separation of carbon dioxide, carbon monoxide, nitrogen and oxygen.

\section{Results and discussions}

\subsection{Metal loading and CO conversion over $A u / Y(N P), A u / Y$ and $[A u / Y(N P)]_{p H}$}

Table 1 lists the metal loading in $\mathrm{Au} / \mathrm{Y}(\mathrm{NP}), \mathrm{Au} / \mathrm{Y}$, $[\mathrm{Au} / \mathrm{Y}(\mathrm{NP})]_{\mathrm{pH}}$ and in each supports before loading gold. For Y-type zeolite, the amount of aluminum is decreased with an increase of sodium after the surface modification. It is because some of aluminum in
Table 1

Metal loadings in Y-type zeolites

\begin{tabular}{llllll}
\hline Catalyst & \multicolumn{3}{l}{ Metal loading (wt.\%) } & \multicolumn{2}{c}{$\begin{array}{l}\text { pH of } \\
\text { filtrate }^{\mathrm{a}}\end{array}$} \\
\cline { 2 - 5 } & $\mathrm{Au}$ & $\mathrm{Fe}$ & $\mathrm{Al}$ & $\mathrm{Na}$ & \\
\hline $\mathrm{Y}(\mathrm{NP})$ & - & - & 14.4 & 3.4 & - \\
$\mathrm{Y}$ & - & - & 12.6 & 5.1 & - \\
$\mathrm{Au} / \mathrm{Y}(\mathrm{NP})$ & 1.59 & - & 12.8 & 2.4 & 6.7 \\
$\mathrm{Au} / \mathrm{Y}$ & 1.70 & - & 12.4 & 3.0 & 6.8 \\
{$[\mathrm{Au} / \mathrm{Y}(\mathrm{NP})]_{\mathrm{pH}}$} & 0.90 & - & 12.7 & 2.5 & 7.0 \\
$\mathrm{Fe}-\mathrm{imp} / \mathrm{Y}$ & - & 3.82 & 12.5 & - & - \\
$\mathrm{Fe}-\mathrm{ion} / \mathrm{Y}$ & - & 4.45 & 8.8 & - & - \\
$\mathrm{Au} / \mathrm{Fe}-\mathrm{imp} / \mathrm{Y}$ & 3.56 & 3.61 & 12.2 & - & 6.7 \\
$\mathrm{Au} / \mathrm{Fe}-\mathrm{ion} / \mathrm{Y}$ & 3.62 & 4.21 & 8.7 & - & 6.4 \\
\hline
\end{tabular}

${ }^{\mathrm{a}} \mathrm{pH}$ of the filtrate after the process of loading gold in the chloroauric acid solution.

Y-type zeolite was leached out and some of the proton on the ion exchange sites in Y-type zeolite was exchanged by sodium ions in the $1 \mathrm{~N} \mathrm{NaNO}_{3}$ solution. The XRD results showed that all the structures of Y-type catalysts were maintained after surface modification. Thus, it is suggested that the modification of Y-type zeolite only caused a change of the surface properties and there was no significant collaps e of the zeolite structure. Interestingly, it can be found in Table 1 that the gold loading in $\mathrm{Au} / \mathrm{Y}$ is higher than that in $\mathrm{Au} / \mathrm{Y}(\mathrm{NP})$, and the $\mathrm{pH}$ values of the filtrates after the preparation of gold in $\mathrm{Au} / \mathrm{Y}$ and $\mathrm{Au} / \mathrm{Y}(\mathrm{NP})$ are in a close range. This indicates that the gold species in the solutions for the preparation of these two catalysts were similar. The different surface property of $\mathrm{Y}$ and $\mathrm{Y}(\mathrm{NP})$ caused different gold loadings in $\mathrm{Au} / \mathrm{Y}$ and $\mathrm{Au} / \mathrm{Y}(\mathrm{NP})$. Therefore, if there are any more different physical or catalytic properties of these two in the later studies, it should be from the effect of surface property during gold loading process.

Fig. 1 shows the experimental results of $\mathrm{CO}$ conversions over as-prepared $\mathrm{Au} / \mathrm{Y}(\mathrm{NP}), \mathrm{Au} / \mathrm{Y}$ and $[\mathrm{Au} / \mathrm{Y}(\mathrm{NP})]_{\mathrm{pH}}$ catalysts (each contained $0.0006 \mathrm{~g}$ of $\mathrm{Au}$ ) at $40^{\circ} \mathrm{C}$. It was found that $\mathrm{Au} / \mathrm{Y}$, shown in Fig. 1a, from surface modified $\mathrm{Y}$ maintained a $\mathrm{CO}$ conversion close to $99 \%$ for at least $48 \mathrm{~h}$. Nevertheless, $\mathrm{Au} / \mathrm{Y}(\mathrm{NP})$, shown in Fig. 1b, had an initial conversion of $66 \%$. Its catalytic activity decayed rapidly at the first $5 \mathrm{~h}$, then to a CO conversion of $38 \%$ after $48 \mathrm{~h}$. $[\mathrm{Au} / \mathrm{Y}(\mathrm{NP})]_{\mathrm{pH}}$ in Fig. 1c showed the lowest CO conversion among these three catalysts. It had very low initial activity and then reached a conversion of $15 \%$ 


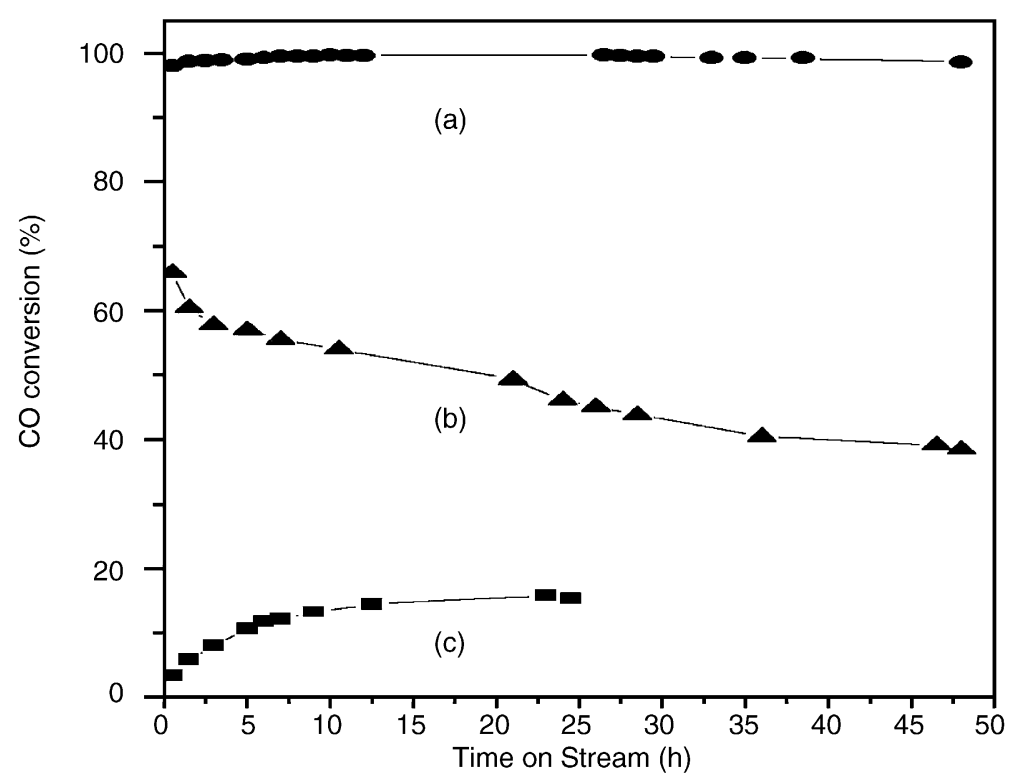

Fig. 1. CO conversion vs. time on stream at $40{ }^{\circ} \mathrm{C}$ over (a) $\mathrm{Au} / \mathrm{Y}$, (b) $\mathrm{Au} / \mathrm{Y}(\mathrm{NP})$, and (c) $[\mathrm{Au} / \mathrm{Y}(\mathrm{NP})]_{\mathrm{pH}}$, which contained $0.0006 \mathrm{~g}$ of gold.

after $24 \mathrm{~h}$. From these results, it can be concluded that the surface modification process for Y-type zeolite used in this research is an effective way to enhance the catalytic property of $\mathrm{Au} / \mathrm{Y}$ for $\mathrm{CO}$ oxidation. However, by adjusting the solution $\mathrm{pH}$ during gold loading process, i.e. for making $[\mathrm{Au} / \mathrm{Y}(\mathrm{NP})]_{\mathrm{pH}}$, is not effective for improving the catalytic property; in fact, it is worse than without.

\subsection{TEM and zeta potential of $A u / Y(N P)$, $A u / Y$ and $[A u / Y(N P)]_{p H}$}

In order to understand why $\mathrm{Au} / \mathrm{Y}(\mathrm{NP}), \mathrm{Au} / \mathrm{Y}$ and $[\mathrm{Au} / \mathrm{Y}(\mathrm{NP})]_{\mathrm{pH}}$ possess different catalytic properties, TEM experiments were carried out. Fig. 2 shows the results. It can be observed that there are two kinds of gold particles on or in both $\mathrm{Au} / \mathrm{Y}(\mathrm{NP})$ and $\mathrm{Au} / \mathrm{Y}$. One is from large particles on the external surface of the supports, the other is from small nanoparticles within the cages. For $\mathrm{Au} / \mathrm{Y}(\mathrm{NP})$, the large gold particles (in Fig. 2a) are between 10 and $15 \mathrm{~nm}$, which are much larger than those (shown in Fig. 2b) around $5 \mathrm{~nm}$ on $\mathrm{Au} / \mathrm{Y}$. The smaller gold particles in both $\mathrm{Au} / \mathrm{Y}(\mathrm{NP})$ and $\mathrm{Au} / \mathrm{Y}$ are $<2 \mathrm{~nm}$. However, most gold particles on $[\mathrm{Au} / \mathrm{Y}(\mathrm{NP})]_{\mathrm{pH}}$ are larger than $20 \mathrm{~nm}$ as shown in Fig. 2c. The larger gold particles would provide less surface area for the reaction. Therefore, the gold particle sizes observed from TEM have given a good explanation why $[\mathrm{Au} / \mathrm{Y}(\mathrm{NP})]_{\mathrm{pH}}$ had the lowest $\mathrm{CO}$ conversion, and why the $\mathrm{CO}$ conversion over $\mathrm{Au} / \mathrm{Y}$ was higher and more stable than that over $\mathrm{Au} / \mathrm{Y}(\mathrm{NP})$.

The zeta potential can represent the amount of surface charges on $\mathrm{Y}(\mathrm{NP})$ and $\mathrm{Y}$. The zeta potential is $-3 \mathrm{mV}$ on $\mathrm{Y}(\mathrm{NP})$ and is $-10 \mathrm{mV}$ on $\mathrm{Y}$ at $\mathrm{pH} 6$. These negative charges can prevent vigorous deposition of gold species with negative charges, such as $\mathrm{Au}(\mathrm{OH})_{4-x} \mathrm{Cl}_{x}{ }^{-}$, on the surface of zeolites. Since there are more negative charges on $\mathrm{Y}$ than those on $\mathrm{Y}(\mathrm{NP})$, the deposition of negative gold species on $\mathrm{Y}$ should be less than those on Y(NP). This may be one of the reasons why the gold particle sizes on the external surface of $\mathrm{Au} / \mathrm{Y}$ is smaller than those of $\mathrm{Au} / \mathrm{Y}(\mathrm{NP})$. Nevertheless, if the deposition of negative gold species were the only path for loading gold species on Y-type zeolite, the gold loading in Au/Y(NP) should have been higher than that in $\mathrm{Au} / \mathrm{Y}$. In fact, it is just the opposite as shown in the data of Table 1. Therefore, there must be some other paths (e.g. cation deposition or cation exchange) for loading gold species in Y-type zeolite in the solution. 

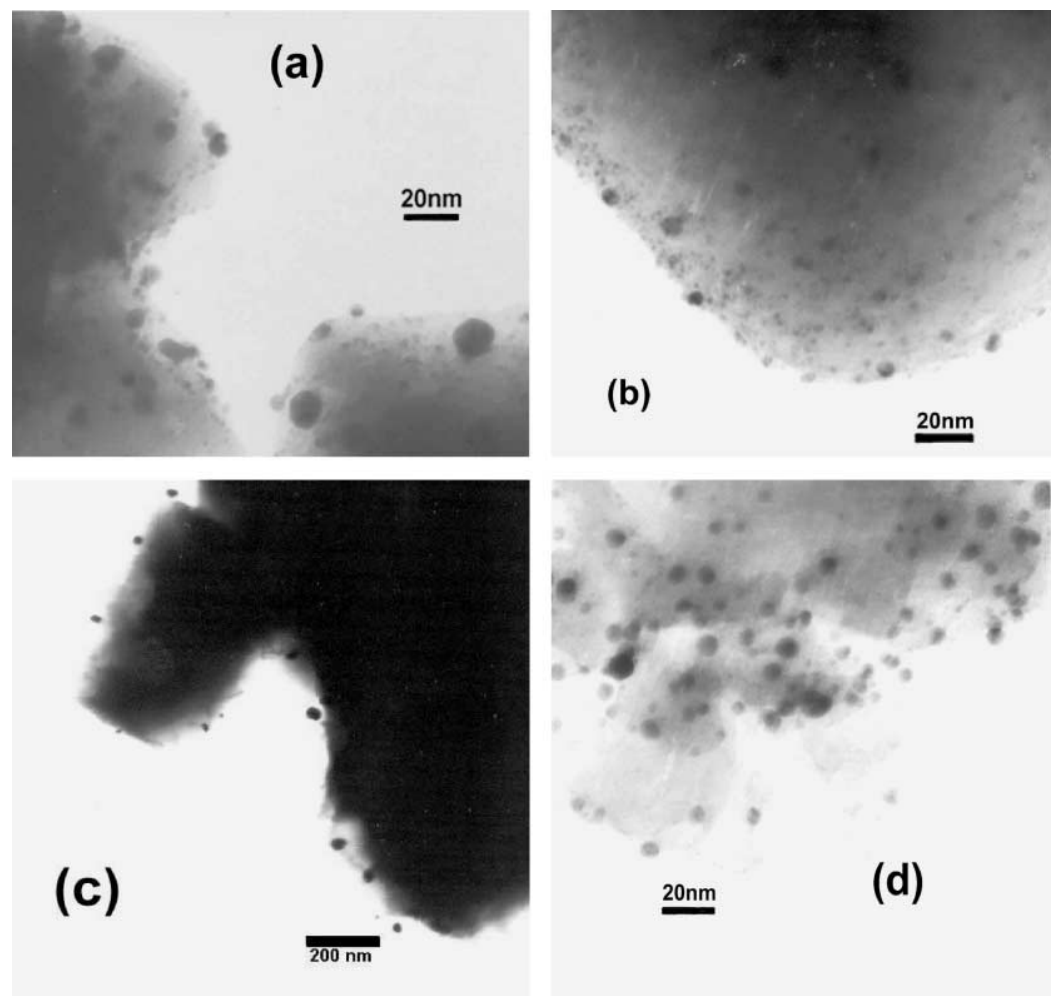

Fig. 2. TEM photographs of (a) $\mathrm{Au} / \mathrm{Y}(\mathrm{NP})$ (b) $\mathrm{Au} / \mathrm{Y}$, (c) $[\mathrm{Au} / \mathrm{Y}(\mathrm{NP})]_{\mathrm{pH}}$, and (d) $\mathrm{Au} / \mathrm{Y}$ after CO reaction.

Although the solution $\mathrm{pH}$ of $[\mathrm{Au} / \mathrm{Y}(\mathrm{NP})]_{\mathrm{pH}}$ was adjusted to $\mathrm{pH} 6.8$, which was the same $\mathrm{pH}$ value at the end of preparation process for $\mathrm{Au} / \mathrm{Y}$, the gold particle sizes and the gold loading on $[\mathrm{Au} / \mathrm{Y}(\mathrm{NP})]_{\mathrm{pH}}$ were not close to those on $\mathrm{Au} / \mathrm{Y}$. $[\mathrm{Au} / \mathrm{Y}(\mathrm{NP})]_{\mathrm{pH}}$ possesses a much lower gold loading, $0.9 \mathrm{wt} . \%$, and much larger gold particles than Au/Y. This indicates that this solution adjustment only mainly changed the $\mathrm{pH}$ of the gold solution. The limited adjustment time was not sufficient to change the surface properties of Y(NP) to $\mathrm{Y}$ (note, it took 2 days to prepare $\mathrm{Y}$ from $\mathrm{Y}(\mathrm{NP})$ as illustrated in Section 2). However, the higher solution $\mathrm{pH}$ for $[\mathrm{Au} / \mathrm{Y}(\mathrm{NP})]_{\mathrm{pH}}$ produced more gold hydroxide, $\mathrm{Au}(\mathrm{OH})_{3}$ and $\mathrm{Au}(\mathrm{OH})_{3} \mathrm{Cl}^{-}$. These gold species formed larger gold particles in the solution via a condensation process of the hydroxyl groups. Some of them would be too large to access into the cages of zeolite. Therefore, for $[\mathrm{Au} / \mathrm{Y}(\mathrm{NP})]_{\mathrm{pH}}$, the gold loading was less and the gold particles were larger than those on $\mathrm{Au} / \mathrm{Y}$ and $\mathrm{Au} / \mathrm{Y}(\mathrm{NP})$.

\subsection{XPS spectra over $A u / Y(N P), A u / Y$ and $[A u / Y(N P)]_{p H}$}

The spectra corresponding to gold are shown in Fig. 3. It can be observed that there are several gold species on these catalysts. After deconvolution, the fitting results are listed in Table 2. The gold species can be classified into metallic gold (Au) and ionic gold $\left(\mathrm{Au}^{3+}\right)$. For $\mathrm{Au}^{3+}$ on $\mathrm{Au} / \mathrm{Y}$, shown in Fig. 3a, at least two different gold species can be observed. One is $\mathrm{Au}(\mathrm{OH})_{2}{ }^{+}$and the other is $\mathrm{Au}_{2} \mathrm{O}_{3}$ gold dimers. However, for $\mathrm{Au}^{3+}$ on $\mathrm{Au} / \mathrm{Y}(\mathrm{NP})$ and $[\mathrm{Au} / \mathrm{Y}(\mathrm{NP})]_{\mathrm{pH}}$, shown in Fig. $3 b$ and c, only $\mathrm{Au}_{2} \mathrm{O}_{3}$ is found. It is noticed that the $\mathrm{BE}$ of $\mathrm{Au}_{2} \mathrm{O}_{3}$ from this research is very close to that in $\mathrm{Au} / \mathrm{Fe}_{2} \mathrm{O}_{3}$ and $\mathrm{Au} / \mathrm{Al}_{2} \mathrm{O}_{3}$ [19]. Nevertheless, the $\mathrm{BE}$ of $\mathrm{Au}(\mathrm{OH})_{2}{ }^{+}$is higher than that of $\mathrm{Au}(\mathrm{OH})_{3}$ in $\mathrm{Au} / \mathrm{Al}_{2} \mathrm{O}_{3}$ by about $0.5 \mathrm{eV}$ [19]. This is reasonable because gold in cationic gold hydroxides certainly possess higher $\mathrm{BE}$ than that in the neutral gold hydroxide. On the other hand, for metallic Au, 


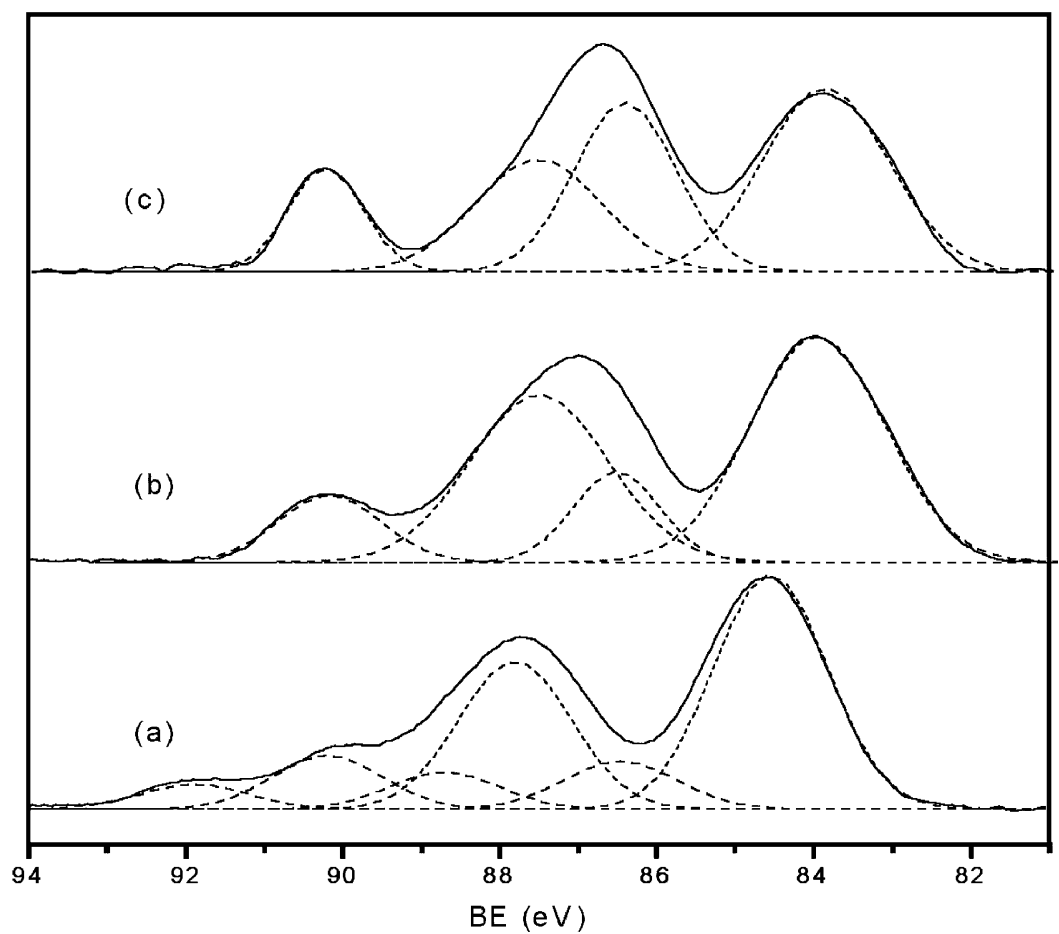

Fig. 3. XPS spectra of (a) $\mathrm{Au} / \mathrm{Y}$ (b) $\mathrm{Au} / \mathrm{Y}(\mathrm{NP})$, and (c) $[\mathrm{Au} / \mathrm{Y}(\mathrm{NP})]_{\mathrm{pH}}$. All the catalysts were dried at room temperature.

it is noticed that $\mathrm{BE}$ of the three gold catalysts, listed in Table 2, are different. The BE of metallic gold on $\mathrm{Au} / \mathrm{Y}$ catalysts is higher than those on $\mathrm{Au} / \mathrm{Y}(\mathrm{NP})$ and $[\mathrm{Au} / \mathrm{Y}(\mathrm{NP})]_{\mathrm{pH}}$, which show $\mathrm{BE}$ values similar to that of bulk gold $(\mathrm{BE}<84 \mathrm{eV})$ [20]. This suggests the existence of small gold metal clusters in $\mathrm{Au} / \mathrm{Y}$, because Rao et al. [21] have observed similar BE shifts of the $\mathrm{Au} 4 \mathrm{f}$ lines of the small gold clusters. In general, small gold clusters with a mean diameter $<2 \mathrm{~nm}$ show significantly larger BE than the bulk gold metal. Therefore, the gold particles in Au/Y should be smaller than $2 \mathrm{~nm}$ from our XPS study. This result is consistent with that observed from the TEM photographs. Moreover, Table 2 lists the XPS peak widths (full-widths at half-maximum band intensity, FWHM) of metallic gold. It can be found that FWHM from $\mathrm{Au} / \mathrm{Y}(\mathrm{NP})$, $1.7 \mathrm{eV}$, and that from $[\mathrm{Au} / \mathrm{Y}(\mathrm{NP})]_{\mathrm{pH}}, 1.6 \mathrm{eV}$, are larger than that from $\mathrm{Au} / \mathrm{Y}, 1.4 \mathrm{eV}$. These results indicate

Table 2

Binding energies of $\mathrm{Au} 4 \mathrm{f}_{7 / 2}$ on $\mathrm{Au} / \mathrm{Y}, \mathrm{Au} / \mathrm{Y}(\mathrm{NP})$ and $[\mathrm{Au} / \mathrm{Y}(\mathrm{NP})]_{\mathrm{pH}}$

\begin{tabular}{|c|c|c|c|c|c|}
\hline \multirow[t]{3}{*}{ Catalysts $^{\mathrm{a}}$} & \multicolumn{3}{|c|}{$\mathrm{Au} 4 \mathrm{f}_{7 / 2}(\mathrm{eV})$} & \multirow[t]{3}{*}{ Peak area ratio $\left(\mathrm{Au}: \mathrm{Au}^{3+}\right)$} & \multirow[t]{3}{*}{$\mathrm{FWHM}^{\mathrm{b}}$ of metallic gold } \\
\hline & \multirow[t]{2}{*}{$\mathrm{Au}$} & \multicolumn{2}{|l|}{$\mathrm{Au}^{3+}$} & & \\
\hline & & $\mathrm{Au}_{2} \mathrm{O}_{3}$ & $\mathrm{Au}(\mathrm{OH})_{2}{ }^{+}$ & & \\
\hline $\mathrm{Au} / \mathrm{Y}$ & 84.4 & 86.4 & 88.2 & 2.0 & 1.4 \\
\hline $\mathrm{Au} / \mathrm{Y}(\mathrm{NP})$ & 84.0 & 86.5 & & 3.7 & 1.7 \\
\hline$[\mathrm{Au} / \mathrm{Y}(\mathrm{NP})]_{\mathrm{pH}}$ & 83.9 & 86.4 & & 1.5 & 1.6 \\
\hline
\end{tabular}

${ }^{a}$ All the samples were dried at room temperature.

${ }^{\mathrm{b}}$ Full-widths at half-maximum intensities. 
that there are wider-spreading small and large metallic gold particles on $\mathrm{Au} / \mathrm{Y}(\mathrm{NP})$ and $[\mathrm{Au} / \mathrm{Y}(\mathrm{NP})]_{\mathrm{pH}}$. The metallic gold particles in $\mathrm{Au} / \mathrm{Y}$ are more uniformly distributed. This is also consistent with the TEM results.

During the process for loading gold on $\mathrm{Y}(\mathrm{NP})$ and $\mathrm{Y}$ in a dilute chloroauric acid solution in this research, since similar solution pHs were monitored, therefore, it is thought that $\mathrm{Au}(\mathrm{OH})_{2}{ }^{+}, \mathrm{Au}_{2} \mathrm{O}_{3}$ (gold dimers) and gold metals should have been prepared on $\mathrm{Au} / \mathrm{Y}(\mathrm{NP})$ and $\mathrm{Au} / \mathrm{Y}$. In fact, only XPS results from $\mathrm{Au} / \mathrm{Y}$ showed $\mathrm{Au}^{3+}$ bands corresponding to $\mathrm{Au}(\mathrm{OH})_{2}{ }^{+}$and $\mathrm{Au}_{2} \mathrm{O}_{3}$; those from $\mathrm{Au} / \mathrm{Y}(\mathrm{NP})$ showed the only $\mathrm{Au}^{3+}$ band corresponding to $\mathrm{Au}_{2} \mathrm{O}_{3}$. The disappearance of $\mathrm{Au}(\mathrm{OH})_{2}{ }^{+}$on $\mathrm{Au} / \mathrm{Y}(\mathrm{NP})$ suggests that the transformation of $\mathrm{Au}(\mathrm{OH})_{2}{ }^{+}$to $\mathrm{Au}_{2} \mathrm{O}_{3}$ was faster on $\mathrm{Au} / \mathrm{Y}(\mathrm{NP})$ than on $\mathrm{Au} / \mathrm{Y}$. This is attributed to the different surface properties of $\mathrm{Au} / \mathrm{Y}(\mathrm{NP})$ and $\mathrm{Au} / \mathrm{Y}$. Since the surface of $\mathrm{Y}(\mathrm{NP})$ is not modified before gold loading, there are more $\mathrm{H}^{+}$on $\mathrm{Au} / \mathrm{Y}(\mathrm{NP})$ than that on $\mathrm{Au} / \mathrm{Y}$. Apparently, $\mathrm{H}^{+}$on the surface is the catalyst for the dehydration (or condensation) surface reaction of $\mathrm{Au}(\mathrm{OH})_{2}{ }^{+}$to $\mathrm{Au}_{2} \mathrm{O}_{3}$ of gold dimers. Furthermore, it is believed that $\mathrm{H}^{+}$is also responsible for catalyzing the deep condensation reactions of gold ion species on the surface. There may be several $\mathrm{Au}(\mathrm{OH})_{2}{ }^{+}$to react sequentially to form large gold oxide particles. Therefore, although the total gold loading on $\mathrm{Au} / \mathrm{Y}(\mathrm{NP})$ was less than that on $\mathrm{Au} / \mathrm{Y}$, the sequential condensation reactions can cause the gold particle sizes on $\mathrm{Au} / \mathrm{Y}(\mathrm{NP})$ being larger than those on $\mathrm{Au} / \mathrm{Y}$.

Table 2 also lists the peak area ratio of $\mathrm{Au}: \mathrm{Au}^{3+}$ of each catalyst. The data indicate that the ratio of $\mathrm{Au}: \mathrm{Au}^{3+}$ from $\mathrm{Au} / \mathrm{Y}$ is less than that from $\mathrm{Au} / \mathrm{Y}(\mathrm{NP})$. It suggests that the formation rate of metallic gold on the surface of $\mathrm{Au} / \mathrm{Y}$ is slower than that on $\mathrm{Au} / \mathrm{Y}(\mathrm{NP})$. Nevertheless, as shown in Table 2, the ratio of $\mathrm{Au}: \mathrm{Au}^{3+}$ on $[\mathrm{Au} / \mathrm{Y}(\mathrm{NP})]_{\mathrm{pH}}$ is the least among these three gold catalysts. It has been discussed in the previous sections that $[\mathrm{Au} / \mathrm{Y}(\mathrm{NP})]_{\mathrm{pH}}$ was prepared in the solution with higher $\mathrm{pH}$ than $\mathrm{Au} / \mathrm{Y}$ and $\mathrm{Au} / \mathrm{Y}(\mathrm{NP})$. More large gold species were formed and deposited on $[\mathrm{Au} / \mathrm{Y}(\mathrm{NP})]_{\mathrm{pH}}$. Apparently, these large gold species are not in metallic form and it takes time to transform them to gold metal at room temperature. Therefore, $[\mathrm{Au} / \mathrm{Y}(\mathrm{NP})]_{\mathrm{pH}}$ possesses the least ratio of $\mathrm{Au}: \mathrm{Au}^{3+}$.

\subsection{Metal loading and $\mathrm{CO}$ oxidation over $\mathrm{Au} / \mathrm{Fe}$-imp/Y and $\mathrm{Au} / \mathrm{Fe}$-ion/Y}

The effects of surface modification on iron Y-type zeolite for loading gold and for catalytic $\mathrm{CO}$ oxidation were also investigated in this research. Table 1 lists the metal loadings in Fe-imp/Y, Fe-ion/Y, $\mathrm{Au} / \mathrm{Fe}-\mathrm{imp} / \mathrm{Y}$ and $\mathrm{Au} / \mathrm{Fe}-\mathrm{ion} / \mathrm{Y}$. It can be found that a significant amount of aluminum was leached out from Y-type zeolite during iron ion exchange process, due to the low $\mathrm{pH}$ of the solution. After preparing gold into $\mathrm{Y}, \mathrm{Fe}-\mathrm{imp} / \mathrm{Y}$ and $\mathrm{Fe}$-ion/Y, the gold loadings in $\mathrm{Au} / \mathrm{Fe}-\mathrm{imp} / \mathrm{Y}$ and $\mathrm{Au} / \mathrm{Fe}-\mathrm{ion} / \mathrm{Y}$ were two times more than that in $\mathrm{Au} / \mathrm{Y}$. Solution chemistry has shown that colloidal gold and complexed gold $\left(\mathrm{AuCl}_{4-x}(\mathrm{OH})_{x}{ }^{-}\right)$ can react with the forming iron oxide surfaces [22]. The iron sites (in the form of iron cation and iron oxides) on $\mathrm{Fe} / \mathrm{Y}$ were also the sites for $\mathrm{Au}$ deposition, since the surface of iron oxide (with an isoelectric point around $\mathrm{pH}$ 7.0) was positively charged during the gold loading process. Therefore, the presence of iron in Y-type zeolite enhanced the gold loading. XRD patterns showed that all the structures of Y-type zeolite were maintained after the preparation of $\mathrm{Au} / \mathrm{Fe} / \mathrm{Y}$.

Fig. 4 shows the carbon monoxide conversions over $\mathrm{Au} / \mathrm{Y}, \mathrm{Au} / \mathrm{Fe}-\mathrm{imp} / \mathrm{Y}$ and $\mathrm{Au} / \mathrm{Fe}-\mathrm{ion} / \mathrm{Y}$ at $0{ }^{\circ} \mathrm{C}$. All the catalysts were dried at $60^{\circ} \mathrm{C}$ under air before the reactions. It can be observed that both $\mathrm{Au} / \mathrm{Fe}-\mathrm{imp} / \mathrm{Y}$ and $\mathrm{Au} / \mathrm{Fe}-\mathrm{ion} / \mathrm{Y}$ showed high initial activities. The results were different from those over $\mathrm{Au} / \mathrm{Fe}$-imp/Y(NP) and $\mathrm{Au} / \mathrm{Fe}$-ion/Y(NP) reported in our previous research [13], in which $\mathrm{Au} / \mathrm{Fe} / \mathrm{Y}(\mathrm{NP})$ samples possessed almost no catalytic activity for $\mathrm{CO}$ oxidation at reaction temperature as high as $40^{\circ} \mathrm{C}$. Apparently, the surface modification process for $\mathrm{Fe}$-imp/Y and $\mathrm{Fe}$-ion/Y developed in this research is effective for preparing highly active gold and iron supported on Y-type zeolite.

\subsection{Characterization of $A u / Y$ and $A u / F e / Y$ by $T P R$ and XPS}

Fig. 5 shows the TPR profiles of $\mathrm{Fe} / \mathrm{Y}, \mathrm{Au} / \mathrm{Y}$ and $\mathrm{Au} / \mathrm{Fe} / \mathrm{Y}$. It can be observed that the reduction temperature from $\mathrm{Fe}-\mathrm{imp} / \mathrm{Y}$ is around $450{ }^{\circ} \mathrm{C}$. It is higher than that from $\mathrm{Fe}$-ion/Y by $62^{\circ} \mathrm{C}$. This indicates that it is easier to reduce iron ions in $\mathrm{Fe}$-ion/Y than iron oxides in $\mathrm{Fe}$-imp/Y. After the preparation of $\mathrm{Au}$ in surface modified $\mathrm{Fe} / \mathrm{Y}$ to form $\mathrm{Au} / \mathrm{Fe}$-imp/Y 


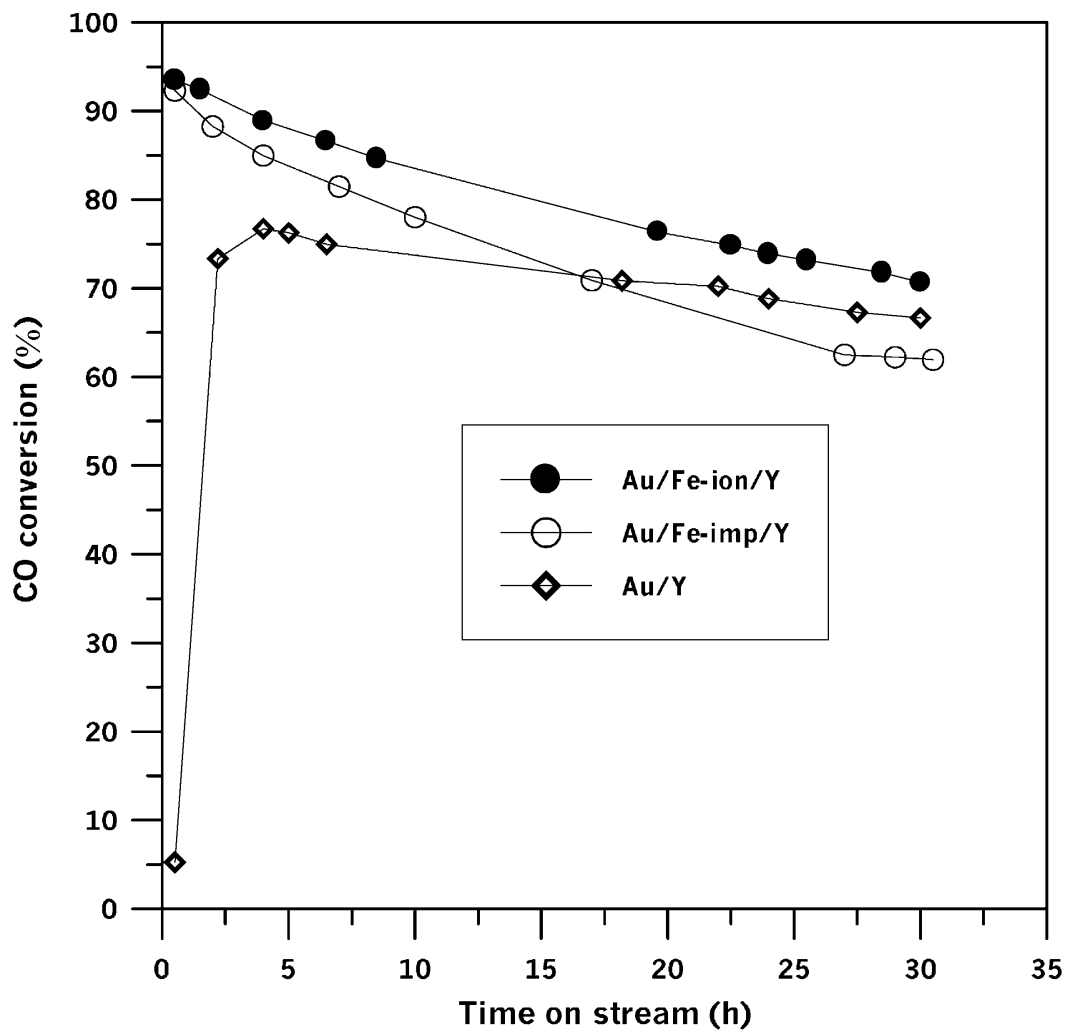

Fig. 4. $\mathrm{CO}$ conversion vs. time on stream at $0{ }^{\circ} \mathrm{C}$ over $\mathrm{Au} / \mathrm{Y}$ and $\mathrm{Au} / \mathrm{Fe} / \mathrm{Y}$. Each catalyst contained $0.0006 \mathrm{~g}$ of gold and was dried at $60{ }^{\circ} \mathrm{C}$ under air before the reaction.

and $\mathrm{Au} / \mathrm{Fe}$-ion/Y, most of the reduction temperatures were dropped to around $100^{\circ} \mathrm{C}$, which were about $50{ }^{\circ} \mathrm{C}$ lower than those from $\mathrm{Au} / \mathrm{Fe}-\mathrm{imp} / \mathrm{Y}(\mathrm{NP})$ and $\mathrm{Au} / \mathrm{Fe}$-ion/Y(NP) prepared in the previous research [13]. This suggests that $\mathrm{Au} / \mathrm{Fe}-\mathrm{imp} / \mathrm{Y}$ and $\mathrm{Au} / \mathrm{Fe}$-ion/Y prepared from this research are easier applied for the oxidation-reduction catalytic reactions than $\mathrm{Au} / \mathrm{Fe}-\mathrm{imp} / \mathrm{Y}(\mathrm{NP})$ and $\mathrm{Au} / \mathrm{Fe}-\mathrm{ion} / \mathrm{Y}(\mathrm{NP})$. Moreover, it is noticed in Fig. 5 that there are single reduction bands for $\mathrm{Au} / \mathrm{Y}$ and $\mathrm{Au} / \mathrm{Fe}$-ion $/ \mathrm{Y}$ around $100^{\circ} \mathrm{C}$. Nevertheless, there are two separable reduction bands at 101 and $125^{\circ} \mathrm{C}$ for $\mathrm{Au} / \mathrm{Fe}$-imp/Y, the former is from the reduction of gold ions and the latter is from the reduction of gold-iron mixed oxides. This indicates that gold and iron oxides in $\mathrm{Au} / \mathrm{Fe}-\mathrm{imp} / \mathrm{Y}$ are not uniformly interacted in Y-type zeolite. However, for $\mathrm{Au} / \mathrm{Fe}$-ion $/ \mathrm{Y}$, the single reduction band around $100{ }^{\circ} \mathrm{C}$ indicates the uniform interaction between gold and iron ions.
Table 3 summarizes the $\mathrm{BE}$ of $\mathrm{Au} 4 \mathrm{f}_{7 / 2}$ and $\mathrm{Fe}$ $2 p_{3 / 2}$ in $\mathrm{Au} / \mathrm{Y}, \mathrm{Au} / \mathrm{Fe}-\mathrm{imp} / \mathrm{Y}$ and $\mathrm{Au} / \mathrm{Fe}$-ion/Y. Different from the samples dried at room temperature listed in Table 2, the samples in Table 3 were dried at $60^{\circ} \mathrm{C}$, prior to evacuation for XPS measurement. It was found from XPS that there was no BE corresponding to $\mathrm{Au}(\mathrm{OH})_{2}{ }^{+}$. There were only two $\mathrm{Au}$ $4 \mathrm{f}_{7 / 2} \mathrm{BE}$, around 84.4 and $86.5 \mathrm{eV}$, the former represents the $\mathrm{BE}$ of metallic gold and the latter represents the $\mathrm{BE}$ of ionic gold $\left(\mathrm{Au}_{2} \mathrm{O}_{3}\right)$. Similar to the results of $\mathrm{Au} / \mathrm{Y}$ in Table 2, higher $\mathrm{BE}$ of metallic gold than that (about $84 \mathrm{eV}$ ) of bulk gold can be observed in Table 3. It indicates the existence of small metallic gold in $\mathrm{Au} / \mathrm{Y}, \mathrm{Au} / \mathrm{Fe}-\mathrm{imp} / \mathrm{Y}$ and $\mathrm{Au} / \mathrm{Fe}$-ion/Y. Therefore, similar to the nanoparticles sizes of gold samples in Table 2, the gold particle sizes in $\mathrm{Au} / \mathrm{Y}, \mathrm{Au} / \mathrm{Fe}-\mathrm{imp} / \mathrm{Y}$ and $\mathrm{Au} / \mathrm{Fe}$-ion $/ \mathrm{Y}$ after dried at $60^{\circ} \mathrm{C}$ are about $2 \mathrm{~nm}$.

The $\mathrm{BE}$ of $\mathrm{Au}_{2} \mathrm{O}_{3}$ from $\mathrm{Au} / \mathrm{Fe}-\mathrm{imp} / \mathrm{Y}$ and $\mathrm{Au} / \mathrm{Fe}-\mathrm{ion} / \mathrm{Y}$ are higher than that from $\mathrm{Au} / \mathrm{Y}$, which 


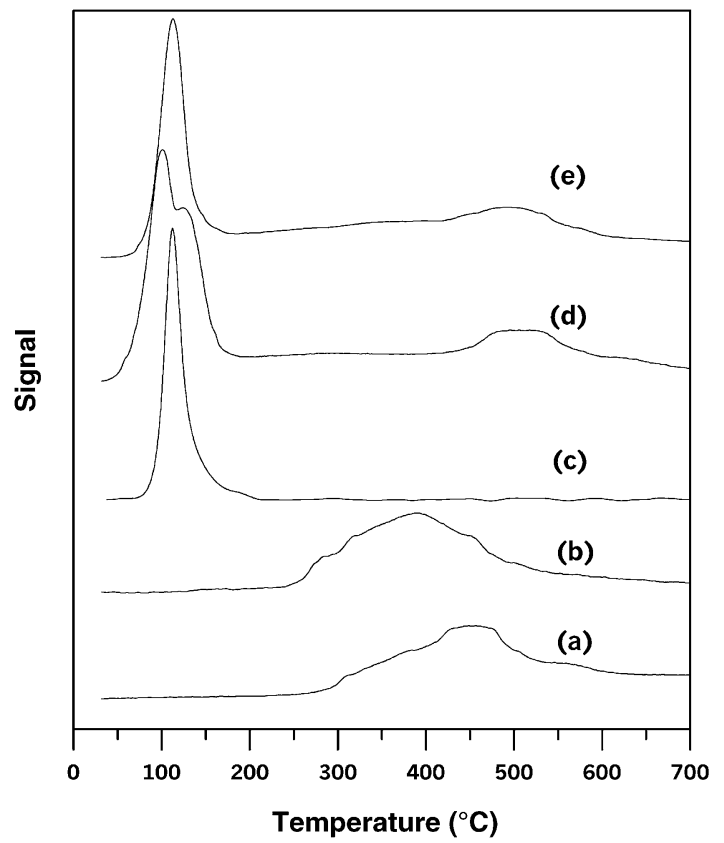

Fig. 5. TPR spectra of (a) Fe-imp/Y, (b) Fe-ion/Y, (c) Au/Y, (d) $\mathrm{Au} / \mathrm{Fe}-\mathrm{imp} / \mathrm{Y}$, and (e) $\mathrm{Au} / \mathrm{Fe}-\mathrm{ion} / \mathrm{Y}$.

indicates an interaction between gold and iron in Y-type zeolite. Because the interaction between gold and iron in $\mathrm{Au} / \mathrm{Fe}$-ion $/ \mathrm{Y}$ is stronger than that in $\mathrm{Au} / \mathrm{Fe}-\mathrm{imp} / \mathrm{Y}$, iron ions in $\mathrm{Au} / \mathrm{Fe}-\mathrm{ion} / \mathrm{Y}$ withdraw more electrons from gold species than iron oxides in $\mathrm{Au} / \mathrm{Fe}-\mathrm{imp} / \mathrm{Y}$. Therefore, it can be observed from Table 3 that the $\mathrm{BE}$ of $\mathrm{Au} 4 \mathrm{f}$ lines from $\mathrm{Au} / \mathrm{Fe}$-ion/Y is higher than that from $\mathrm{Au} / \mathrm{Fe}-\mathrm{imp} / \mathrm{Y}$. Furthermore, the stronger interaction between gold and iron causes the less formation of metallic gold from ionic gold in Y-type zeolite. Therefore, it can be found in Table 3 that the peak area ratios of metallic gold to ionic gold of $\mathrm{Au} / \mathrm{Y}, \mathrm{Au} / \mathrm{Fe}-\mathrm{imp} / \mathrm{Y}$, and $\mathrm{Au} / \mathrm{Fe}-\mathrm{ion} / \mathrm{Y}$ are 1.5, 1 , and 0.25 , respectively. $\mathrm{Au} / \mathrm{Y}$ possessed the most metallic gold, and $\mathrm{Au} / \mathrm{Fe}-\mathrm{ion} / \mathrm{Y}$ possessed the least.

Table 3 also lists the BE of $\mathrm{Fe} 2 \mathrm{p}_{3 / 2}$ in $\mathrm{Au} / \mathrm{Fe}$-imp/Y and $\mathrm{Au} / \mathrm{Fe}$-ion/Y. The BE of $\mathrm{Fe} 2 \mathrm{p}_{3 / 2}$ in $\mathrm{Au} / \mathrm{Fe}$-imp/Y and $\mathrm{Au} / \mathrm{Fe}-\mathrm{ion} / \mathrm{Y}$ are 711.6 and $710.7 \mathrm{eV}$. It indicates that iron in $\mathrm{Au} / \mathrm{Fe}-\mathrm{ion} / \mathrm{Y}$ is at a lower oxidation state than that in $\mathrm{Au} / \mathrm{Fe}-\mathrm{imp} / \mathrm{Y}$. These results are consistent with the previous discussion, while iron in $\mathrm{Au} / \mathrm{Fe} / \mathrm{Y}$ pull more electrons from gold than that in $\mathrm{Au} / \mathrm{Fe}$-imp/Y, due to stronger interaction between gold and iron in $\mathrm{Au} / \mathrm{Fe}-\mathrm{ion} / \mathrm{Y}$. Furthermore, it was reported that $\alpha-\mathrm{Fe}_{2} \mathrm{O}_{3}, \mathrm{FeO}, \mathrm{Fe}_{3} \mathrm{O}_{4}$, and $\mathrm{FeOOH}$ have $\mathrm{Fe} 2 \mathrm{p}_{3 / 2} \mathrm{BE}$ values at 711.6, 709.6, 710.8 and $711.2 \mathrm{eV}$, respectively [23]. Therefore, it was $\mathrm{Fe}_{2} \mathrm{O}_{3}$ in $\mathrm{Au} / \mathrm{Fe}-\mathrm{imp} / \mathrm{Y}$; and it was iron ions (with an oxidation state similar to that of $\mathrm{Fe}$ in $\mathrm{Fe}_{3} \mathrm{O}_{4}$ ) in $\mathrm{Au} / \mathrm{Fe}$-ion/Y.

\subsection{Comparison of $\mathrm{CO}$ oxidation activity over $\mathrm{Au} / \mathrm{Y}$ and $\mathrm{Au} / \mathrm{Fe} / \mathrm{Y}$}

All the catalysts were dried under air at $60^{\circ} \mathrm{C}$ prior to the reaction tests. The reaction results of $\mathrm{CO}$ oxidation at $0^{\circ} \mathrm{C}$, as shown in Fig. 4 , present that the initial catalytic activity of $\mathrm{Au} / \mathrm{Y}$ and $\mathrm{Au} / \mathrm{Fe} / \mathrm{Y}$ are different. For both $\mathrm{Au} / \mathrm{Fe}-\mathrm{ion} / \mathrm{Y}$ and $\mathrm{Au} / \mathrm{Fe}-\mathrm{imp} / \mathrm{Y}$, the initial high CO conversions (more than $90 \%$ ) were

Table 3

Binding energies of $\mathrm{Au} 4 \mathrm{f}_{7 / 2}$ and $\mathrm{Fe} 2 \mathrm{p}_{3 / 2}$ on $\mathrm{Au} / \mathrm{Y}$ and $\mathrm{Au} / \mathrm{Fe} / \mathrm{Y}$ after dried in air at $60^{\circ} \mathrm{C}$

\begin{tabular}{|c|c|c|c|c|c|c|c|}
\hline \multirow[t]{2}{*}{ Catalyst $^{\mathrm{a}}$} & \multicolumn{2}{|c|}{$\mathrm{Au} 4 \mathrm{f}_{7 / 2}(\mathrm{eV})$} & \multirow[t]{2}{*}{$\mathrm{Fe} 2 \mathrm{p}_{3 / 2}(\mathrm{eV})$} & \multicolumn{4}{|c|}{ Peak area ratio } \\
\hline & $\mathrm{Au}$ & $\mathrm{Au}_{2} \mathrm{O}_{3}$ & & $\mathrm{Au}: \mathrm{Au}^{3+}$ & $\mathrm{Cl}: \mathrm{Au}_{\mathrm{t}}{ }^{\mathrm{d}}$ & $\mathrm{Au}_{\mathrm{t}}: \mathrm{Fe}$ & $\mathrm{C}: \mathrm{Au}_{\mathrm{t}}$ \\
\hline \multirow[t]{3}{*}{$\mathrm{Au} / \mathrm{Y}$} & 84.4 & 86.5 & - & 1.5 & 1.5 & - & 14 \\
\hline & $83.8^{\mathrm{b}}$ & - & - & 0.0 & - & - & \\
\hline & $84.0^{\mathrm{c}}$ & - & - & 0.0 & - & 15 & \\
\hline \multirow[t]{2}{*}{$\mathrm{Au} / \mathrm{Fe}-\mathrm{imp} / \mathrm{Y}$} & 84.4 & 86.6 & 711.6 & 1.0 & 1.5 & 1.6 & 15 \\
\hline & $84.1^{\mathrm{c}}$ & 711.2 & - & 0.0 & 0.7 & 240 & \\
\hline $\mathrm{Au} / \mathrm{Fe}-\mathrm{ion} / \mathrm{Y}$ & 84.7 & 86.8 & 710.7 & 0.25 & 1.2 & 0.7 & - \\
\hline
\end{tabular}

${ }^{\text {a }}$ All the samples were dried in air at $60^{\circ} \mathrm{C}$ prior to evacuation for XPS measurement.

${ }^{b}$ After TPR in $\mathrm{H}_{2}: \mathrm{N}_{2}=1: 9$ until $800{ }^{\circ} \mathrm{C}$.

${ }^{\mathrm{c}}$ After $\mathrm{CO}$ oxidation at $0{ }^{\circ} \mathrm{C}$ for $30 \mathrm{~h}$.

${ }^{\mathrm{d}} \mathrm{Au}_{\mathrm{t}}$ : the sum of XPS area of total gold $\left(\mathrm{Au}\right.$ and $\left.\mathrm{Au}^{3+}\right)$. 
obtained. Nevertheless, there was almost no initial activity for $\mathrm{Au} / \mathrm{Y}$. It can be activated and reached a $75 \%$ $\mathrm{CO}$ conversion after an induction period of about $4 \mathrm{~h}$ at $0{ }^{\circ} \mathrm{C}$. However, the stability of $\mathrm{Au} / \mathrm{Y}$ after activation was better than that of $\mathrm{Au} / \mathrm{Fe} / \mathrm{Y}$ catalysts. It can be observed from Fig. 4 that the activity decaying rates of $\mathrm{Au} / \mathrm{Fe} / \mathrm{Y}$ are higher than that of $\mathrm{Au} / \mathrm{Y}$. After reaction time on stream for $30 \mathrm{~h}$, it was observed that the activity of $\mathrm{Au} / \mathrm{Y}$ had been higher than that of $\mathrm{Au} / \mathrm{Fe}-\mathrm{imp} / \mathrm{Y}$ and slightly less than that of $\mathrm{Au} / \mathrm{Fe}-\mathrm{ion} / \mathrm{Y}$.

From the gold solution chemistry [24], it was found that $\mathrm{AuCl}_{2}(\mathrm{OH})_{2}{ }^{-}$and $\mathrm{AuCl}(\mathrm{OH})_{3}{ }^{-}$were the predominant gold complexes in the $\mathrm{pH}$ range of 6-7 at a transient state. Therefore, it was inevitable to possess some chloride ions over these gold catalysts. As shown XPS results in Table 3, all the gold catalysts contained a $\mathrm{Cl}: \mathrm{Au}$ ratio around 1.5 and these residual surface chloride ions were not detected on the catalysts after $\mathrm{CO}$ reaction. The nearly no initial activity of $\mathrm{Au} / \mathrm{Y}$ at $0^{\circ} \mathrm{C}$ may be from that its surface was covered with some chloride ions. For $\mathrm{Au} / \mathrm{Y}$, therefore, it took a period of initiation time to remove these surface chlorides. However, $\mathrm{Au} / \mathrm{Fe} / \mathrm{Y}$ did not need any initiation time for $\mathrm{CO}$ oxidation at $0{ }^{\circ} \mathrm{C}$. The co-existence of iron in $\mathrm{Au} / \mathrm{Fe} / \mathrm{Y}$ might help to remove the chloride ions from gold species more easily.

The reaction mechanisms for $\mathrm{CO}$ oxidation over gold catalyst are still under discussion. It was concluded that the catalytic $\mathrm{CO}$ oxidation mechanism over $\mathrm{Au} / \mathrm{Fe}_{2} \mathrm{O}_{3}$ [25-26] was different from that over $\mathrm{Au} / \mathrm{TiO}_{2}$ [27] and polycrystalline gold [28]. For $\mathrm{Au} / \mathrm{Fe}_{2} \mathrm{O}_{3}$, it was shown that iron oxide was the oxygen provider for the reaction. And the reaction mechanism involves the removal and replenishment of lattice oxygen, where the presence of gold promotes these processes. For $\mathrm{Au} / \mathrm{TiO}_{2}$ and polycrystalline gold, the $\mathrm{CO}$ oxidation occurred via a Langmuir-Hinshelwood (L-H)-type mechanism, i.e. simultaneous adsorption and reaction of $\mathrm{CO}$ and $\mathrm{O}$ at gold sites. However, Boccuzzi et al. [29] suggested that two independent pathways might exist for the reaction. One occurred rapidly and directly at the surface of the metallic gold particles and the other was slower and induced by the oxygen in the gas phase, involving the surface lattice oxygen of the supports and of the borderline with the gold particles. Therefore, the $\mathrm{CO}$ reaction over $\mathrm{Au} / \mathrm{Y}$ could be via an $\mathrm{L}-\mathrm{H}$-type mechanism since gold particles were the only possible active sites for $\mathrm{CO}$ oxidation and the dissociative adsorption of oxygen was the rate-determining-step (RDS) for CO oxidation, which was easily inhibited by chloride ions. The $\mathrm{CO}$ oxidation over $\mathrm{Au} / \mathrm{Fe} / \mathrm{Y}$ could be via the two independent reaction pathways [29]. This may be one of the reasons that the initial $\mathrm{CO}$ conversions over $\mathrm{Au} / \mathrm{Fe} / \mathrm{Y}$ were higher than that over $\mathrm{Au} / \mathrm{Y}$.

Furthermore, for $\mathrm{Au} / \mathrm{Fe} / \mathrm{Y}$ catalysts, the more the interaction between gold and iron over $\mathrm{Au} / \mathrm{Fe} / \mathrm{Y}$, the more peripheries can be provided for $\mathrm{CO}$ oxidation. XPS results in Table 3 showed that the Au:Fe ratio of $\mathrm{Au} / \mathrm{Fe}-\mathrm{imp} / \mathrm{Y}$ (1.6) was two times larger than that of $\mathrm{Au} / \mathrm{Fe}-\mathrm{ion} / \mathrm{Y}(0.7)$. This suggests that there were more peripheries existed per unit mass gold particles over $\mathrm{Au} / \mathrm{Fe}$-ion/Y. This is consistent with the TPR results. Therefore, the difference between $\mathrm{Au} / \mathrm{Fe}$-imp/Y and $\mathrm{Au} / \mathrm{Fe}-\mathrm{ion} / \mathrm{Y}$ for $\mathrm{CO}$ oxidation was due to the different dispersions of gold species over $\mathrm{Au} / \mathrm{Fe} / \mathrm{Y}$ catalysts.

However, the catalytic activity of $\mathrm{Au} / \mathrm{Fe} / \mathrm{Y}$ decayed more rapidly than $\mathrm{Au} / \mathrm{Y}$. It was observed from XPS that the C:Au ratio increased enormously in $\mathrm{Au} / \mathrm{Fe}-\mathrm{imp} / \mathrm{Y}$ catalyst after $\mathrm{CO}$ oxidation and the $\mathrm{Au}: \mathrm{Fe}$ ratio of $\mathrm{Au} / \mathrm{Fe}-\mathrm{imp} / \mathrm{Y}$ was also decreased after reaction, as shown in Table 3. Many groups have found that the presence of carbonate-like species occurred during $\mathrm{CO}$ oxidation [25-28]. These species were stable below $100^{\circ} \mathrm{C}$ [25], which were regarded as by-products that were not important for $\mathrm{CO}_{2}$ formation and probably inhibit the reaction of $\mathrm{CO}$ oxidation. It was also observed by Kang and Wan [12] that the deactivation over $\mathrm{Au} / \mathrm{Fe} / \mathrm{Y}$ could be recovered by a thermal treatment under inert gas. Thus, the accumulation of these carbonate-like species over gold-iron peripheries could contribute for the deactivation of $\mathrm{Au} / \mathrm{Fe} / \mathrm{Y}$ catalysts. As the reaction goes further, the carbonate-like species can accumulate more to cover the gold surface, which results in the further deactivation of $\mathrm{Au} / \mathrm{Fe} / \mathrm{Y}$. Finally, gold particles were the only active sites remained for $\mathrm{CO}$ oxidation over $\mathrm{Au} / \mathrm{Fe} / \mathrm{Y}$. Therefore, the activity of $\mathrm{Au} / \mathrm{Y}$ had been higher than that of $\mathrm{Au} / \mathrm{Fe}-\mathrm{imp} / \mathrm{Y}$, and slightly less than that of $\mathrm{Au} / \mathrm{Fe}-\mathrm{ion} / \mathrm{Y}$ after $\mathrm{CO}$ reaction for $30 \mathrm{~h}$.

The deactivation of $\mathrm{Au} / \mathrm{Y}$ for $\mathrm{CO}$ reaction was different from $\mathrm{Au} / \mathrm{Fe} / \mathrm{Y}$. The $\mathrm{C}$ :Au ratios over $\mathrm{Au} / \mathrm{Y}$, listed 
in Table 3, only increased a little after the reaction. Thus, the decrease of $\mathrm{CO}$ activity over $\mathrm{Au} / \mathrm{Y}$ was not likely from the accumulation of carbon coke. It was also indicated in Table 3 that there was only one binding energy of $\mathrm{Au} 4 \mathrm{f}_{7 / 2}$, designated as metallic gold over $\mathrm{Au} / \mathrm{Y}$ catalyst after $\mathrm{CO}$ oxidation and it was close to the $\mathrm{BE}$ of $\mathrm{Au} 4 \mathrm{f}_{7 / 2}$ of bulk gold metals. The TEM results in Fig. 2d showed gold particles in $\mathrm{Au} / \mathrm{Y}$ sintered after $\mathrm{CO}$ oxidation. Therefore, the slight decrease of $\mathrm{CO}$ conversion over $\mathrm{Au} / \mathrm{Y}$ was predominantly from the sintering of nano-gold particles in Y-type zeolite.

\section{Conclusions}

1. Both $\mathrm{Au} / \mathrm{Y}$ and $\mathrm{Au} / \mathrm{Fe} / \mathrm{Y}$ prepared in this research had much higher catalytic activity for $\mathrm{CO}$ oxidation than those $(\mathrm{Au} / \mathrm{Y}(\mathrm{NP})$ and $\mathrm{Au} / \mathrm{Fe} / \mathrm{Y}(\mathrm{NP}))$ prepared from our previous research [11-13].

2. $\mathrm{Au} / \mathrm{Fe} / \mathrm{Y}$ had very high initial activity for $\mathrm{CO}$ oxidation, however, $\mathrm{Au} / \mathrm{Y}$ needed an induction period to be fully activated for $\mathrm{CO}$ oxidation at $0^{\circ} \mathrm{C}$. After fully activated, $\mathrm{Au} / \mathrm{Y}$ possessed similar activity but much better stability than $\mathrm{Au} / \mathrm{Fe} / \mathrm{Y}$.

3. TEM showed that the gold particles size on $\mathrm{Au} / \mathrm{Y}$ was smaller and more uniform distributed than $\mathrm{Au} / \mathrm{Y}(\mathrm{NP})$.

4. From XPS study, $\mathrm{Au}(\mathrm{OH})_{2}{ }^{+}$which has binding energy higher than $\mathrm{Au}(\mathrm{OH})_{3}$ by about $0.5 \mathrm{eV}$ was observed on $\mathrm{Au} / \mathrm{Y}$; however, it was not observed on $\mathrm{Au} / \mathrm{Y}(\mathrm{NP})$.

5. The formation of carbonate-like species, which blocked the active sites for $\mathrm{CO}$ oxidation, was the main reason for the deactivation of $\mathrm{Au} / \mathrm{Fe} / \mathrm{Y}$. On the other hand, the sintering of gold nanoparticles on $\mathrm{Au} / \mathrm{Y}$ was the main reason for the slight deactivation of $\mathrm{Au} / \mathrm{Y}$ after initiation.

6. There was a strong interaction between gold and iron in $\mathrm{Au} / \mathrm{Fe} / \mathrm{Y}$, which was evidenced by XPS and TPR experiments.

\section{Acknowledgements}

The financial support from National Science Council of Taiwan is appreciated.

\section{References}

[1] M. Haruta, T. Kobayashi, H. Sano, N. Yamada, Chem. Lett. (1987) 405

[2] M. Haruta, N. Yamada, T. Kobayashi, S. Iijima, J. Catal. 115 (1989) 301.

[3] M. Haruta, S. Tsubota, T. Kobayashi, H. Kageyama, M.J. Genet, B. Delmon, J. Catal. 144 (1993) 175.

[4] G.C. Bond, D.T. Thompson, Catal. Rev. Sci. Eng. 41 (1999) 319.

[5] A. Knell, P. Barnickel, A. Baiker, A. Wokaun, J. Catal. 137 (1992) 306.

[6] S.D. Lin, M. Bollinger, M.A. Vannice, Catal. Lett. 17 (1993) 245.

[7] M.C. Kung, J.-H. Lee, A. Chu-Kung, H.H. Kung, Stud. Surf. Sci. Catal. 101 (1996) 701.

[8] S. Qiu, R. Ohnishi, M. Ichikawa, J. Phys. Chem. 101 (1994) 2719.

[9] T.M. Salama, T. Shido, H. Minagawa, M. Ichikawa, J. Catal. 152 (1995) 322.

[10] T.M. Salama, R. Ohnishi, M. Ichikawa, J. Chem. Soc., Faraday Trans. 92 (1996) 301.

[11] Y.M. Kang, B.Z. Wan, Appl. Catal. A: Gen. 128 (1995) 53.

[12] Y.-M. Kang, B.-Z. Wan, Catal. Today 26 (1995) 59.

[13] Y.-M. Kang, B.-Z. Wan, Catal. Today 35 (1997) 379.

[14] D. Guillemot, M. Polisset-Thfoin, J. Fraissard, Catal. Lett. 41 (1996) 143.

[15] V.Y. Borovkov, V.B. Kazansky, M. Polisset-Thfoin, J. Fraissard, J. Chem. Soc., Faraday Trans. 93 (1997) 3587.

[16] C.-Y. Hsiao, Improvement and study of gold iron oxide catalysts for carbon monoxide oxidation, M.S. thesis, National Taiwan University, Taiwan, 1994.

[17] J.-H Chen, Redox behavior and catalytic carbon monoxide oxidation of gold/transition metal (3D) zeolite catalysts, M.S. thesis, National Taiwan University, Taiwan, 1996.

[18] Y.-M. Kang, B.-Z. Wan, Appl. Catal. A 114 (1994) 35.

[19] E.D. Park, J.S. Lee, J. Catal. 186 (1999) 1.

[20] C.D. Wagner, W.M. Riggs, L.E. Davis, J.M. Moulder, G.E. Muilenberg, Handbook of X-ray Photoelectron Spectroscopy, Perkin-Elmer, Eden Prairie, 1979.

[21] C.N.R. Rao, V. Vijayakrishnan, H.N. Aiyer, G.U. Kulkarni, G.N. Subbanna, J. Phys. Chem. 97 (1993) 11157.

[22] D.W. Thompson, I.R. Collins, J. Colloid Interface Sci. 152 (1991) 197.

[23] W.S. Epling, G.B. Hoflund, J.F. Weaver, S. Tsubata, M. Haruta, J. Phys. Chem. B 100 (1996) 9929.

[24] P.J. Murphy, M.S. LaGrange, Geochim. Cosmochim. Acta 62 (1998) 3515.

[25] A.K. Tripathi, V.S. Kamble, N.M. Gupta, J. Catal. 187 (1999) 332.

[26] M.M. Schubert, S. Hackenberg, C. van Veen, M. Muhler, V. Plzak, R.J. Behm, J. Catal. 197 (2001) 113.

[27] M.A. Bollinger, M.A. Vannice, Appl. Catal. B: Environ. 8 (1996) 417.

[28] N.M. Gupta, A.K. Tripathi, J. Catal. 187 (1999) 343.

[29] F. Boccuzzi, A. Chiorino, S. Tsubota, M. Haruta, J. Phys. Chem. 100 (1996) 3625. 